\title{
Clustered Genetic Algorithm to solve Multidimensional Knapsack Problem
}

\author{
Dr. Prabha Shreeraj Nair \\ Dean Research \\ Tulsiramji Gayakwade Patil College of Engineering and Technology, Nagpur
}

\begin{abstract}
Genetic Algorithm (GA) has emerged as a powerful tool to discover optimal for multidimensional knapsack problem (MDKP). Multidimensional knapsack problem has recognized as NP-hard problem whose applications in many areas like project selection, capital budgeting, loading problems, cutting stock etc. Attempts has made to develop cluster genetic algorithm (CGA) by mean of modified selection and modified crossover operators of GA. Clustered genetic algorithm consist of (1) fuzzy roulette wheel selection for individual selection to form the mating pool (2) A different kind of crossover operator which employ hierarchical clustering method to form two clusters from individuals of mating pool. CGA performance has examined against GA with respect to 30 benchmark problems for multidimensional knapsack. Experimental results show that CGA has significant improvement over GA in relation to discover optimal and CPU running time. The data set for MDKP is available at http://people.brunel.ac.uk/ mastjjb/jeb/orlib/files/mknap2.txt
\end{abstract}

Keywords: Multidimensional knapsack problem, Genetic algo-rithm, Fitness function, Crossover, Mutation

\section{INTRODUCTION}

Multidimensional knapsack problem is one of the famous problem in applied mathematics belongs to NP- hard combi-natorial optimization [1]. This problem modeling has applied in several project selection and capital budgeting areas [2-4]. Meirier developed more mechanisms from real word practice to combine models of capital budgeting with novels, and practically applicable technique for evaluation of project [5]. They developed scenario dependent capital budgeting model that have MDKP as a subproblem associated with constraint of generalized upper bound (GUB). Capital budgeting emerged as key challenge for not for profits multihospital healthcare units in United States. D.N. Kleinmuntz and C.E. Kleinmuntz developed a framework for capital budeting which used MDKP formulations [6]. MDKP have been employed to model prob-lems like investment policy in tourism area of developing country [7], database allocation and processor allocation in distributed computing environments [8], groceries delivery in vehicles with multiple compartments [9], cutting stock [10], loading problems [11] and approval voting [12]. Currently, MDKP has been applied in modeling of daily management of remote satellite like SPOT, which consisted in deciding each day what photographs will be attempted the next day [13].

Multidimensional knapsack problem is described by $\mathrm{n}$ objects and $\mathrm{m}$ knapsacks. Each knapsack has a capacity $d_{j}(j=1 ; 2 ; 3::: m)$. A number of binary variables $\mathrm{x}_{\mathrm{i}}(\mathrm{i}=1 ; 2 ; 3:: \mathrm{n})$ are used, that is set to 1 if $i^{\text {th }}$ object is chosen to inset in knapsacks otherwise it is set to 0 . Each object has a profit value $p_{i}(i=1 ; 2$; $3:: \mathrm{n})$ and a weight $\mathrm{w}_{\mathrm{ij}}$ corresponding to knapsacks. Thus mathematically this optimization problem can be modeled as :

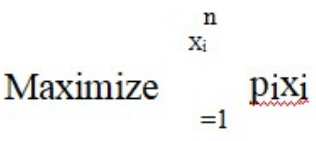

Subject to :

$$
\begin{aligned}
& \mathrm{M}_{\mathrm{X}} \\
& =1 \quad \text { wijxi }_{\mathrm{m}} \mathrm{j}=1 ; 2 ; \cdots \mathrm{m} \\
& \text { xi } 2 \text { f0; } 1 \mathrm{~g} \quad \mathrm{i}=1 ; 2 ; 3: \text { n }
\end{aligned}
$$

The goal of MDKP is to insert a subset of objects into knapsacks that obtain maximum profit without 
capacity viola-tion of knapsacks. This characteristic reveal this problem has all nonnegative entries. More specifically, we can say $p_{i}>0$,

$$
d_{j}>0,0 w_{i j} \quad d_{j} \text { and } \quad w_{i j}^{m} \quad d_{i=1}^{m} \text { for all } i 2 n \text { and } j 2 m
$$

Rest of the paper is structured as follows. Genetic algorithm for MDKP is described in Section II. Section III give the overview of related work for MDKP in domain of genetic algorithm. Section IV explain CGA to solve multidimensional knapsack problem. Experimental environments and results are given in Section V. At last conclusion is made in section VI.

\section{GENETIC ALGORITHM FOR MULTIDIMENSIONAL KNAPSACK PROBLEM}

Genetic algorithm is computation optimization technique which mimic the evolutionary principle i.e. fittest individual will survive in each generation. GA is guided by three main operation: selection, crossover and mutation. Individuals re-production are governed by crossover and mutation operation. Selection operation choose fittest individuals from population to form mating pool. Algorithm run as follow : A set of random individuals are produced which serve as the initial population of GA. The individual can be expressed in real number, binary number, integer number, character based on nature of problem. MDKP uses the binary representation. Individual goodness measurement is estimated through fitness function. MDKP fitness function is maximize the objective function.

\section{Algorithm 1 Genetic Algorithm (GA)}

Initialize the control parameters ;

Initialize randomly $\mathrm{N}$ individuals as initial population $\mathrm{P}$

(G); while stopping criterion(s) doesn't meet do i. Choose individuals to create mating pool via selection operator.

ii.Produce new individuals via crossover operator.

iii. Mutate obtained individuals using mutation operator.

iv. Evaluate fitness value of new individuals.

v. Add new individuals with population.

vi. Sort population with respect to fitness value.

vii. Choose top $\mathrm{N}$ individuals as population of next generation.

end while

Return the fittest individual as the solution.

Every individual are transformed from one generation to next generation depending on fitness value i.e individual with high fitness value has high probability to participate in upcoming generation. GA employee crossover operator for exploration and mutation operator for exploitation. MDKP uses one point crossover and random mutation. Number of crossover operations are govern through crossover rate while number of mutation operations are govern through mutation rate. A cycle of GA comprise of applying GA operations i.e. evaluation, reproduction, crossover and mutation. Each generation produce a set of individuals. GA termination return the fittest individual as solution. The details of GA operators i.e selection, crossover, and mutation are explained in [14].

\section{RELATED WORK}

J.P. Martin and C.B Neto and M.K. Crocomo made compar-ison among four linkage learning based genetic algorithm for multidimensional knapsack problem namely, extended com-pact genetic algorithm (eCGA), bayesian optimization algo-rithm (BOA) with detection graphs, BOA with community detection and linkage tree genetic algorithm (LTGA) [15]. eCGA and LTGA have better exploration and exploitation capabilities than BOA versions with small size population $(\mathrm{N}=100)$ and produce better quality solutions for MDKPs. All algorithms with large population size produce approxi-mately similar quality solutions for MDKPs but these have different running time and function evaluations. When consider solutions quality, functions evaluations and 
running time of algorithms, BOA versions have better running time than eCGA and LTGA. It is very difficult to make comparison for computational time between eCGA and LTGA because these have different reproduction operators.

Khuri, Back and Heitkotter proposed a GA for $0 / 1$ MDKP [16]. Algorithm allowed breeding and participation of infeasi-ble solutions during search. In this GA, reproduction proceeds by combining the partial information from all element of population. A test suite with few problems were used to test this GA; only moderate quality solutions were produced. Hoff, Lokentangen and Mittet proposed a GA with proper tuned parameters and search mechanisms in which only feasible solutions were allowed during search [17]. This GA discovered optimal for 54 problems out a suite of 55 problems.

Rudolph and Sprave proposed a GA in which selection of parent is not unrestricted as in standard GA but is restricted be-tween neighboring solutions [18]. In their GA every infeasible solutions were penalized as GA of Khursi, Back and Heitkotter [16]. The premier component of this GA be solutions local interaction with in a spatial structured population and self ad-justed controlling mechanism of selection pressure. P. C. Chu and J.E. Beasley proposed heuristic dependent GA for MDKP [19]. In their GA heuristic operator was employed which work with problem specific knowledge. Heuristic operator repaired infeasible solutions and algorithm discover optimal solution among feasible solutions. C. Cota and J.M. Troya proposed another GA which have an improvement mechanism whose objective is to convert infeasible solutions in search space to feasible solutions [20]. Experimental results were better to basic GA, but not as good as Chu and Beasley's GA results.
Partition size is relative to fitness value. Next similarity value between first individual and remaining individuals are estimated. The individual with highest similarity value occupy the second partition of roulette wheel. This procedure repeat until all individuals are allocated to partition in roulette wheel. Figure 1 show the 4 individuals in binary representation and procedure of assigning individual to the partition of roulette wheel. Then mechanism determined overlapping area between adjacent individuals. Overlapping area size is correlated by similarity value between adjacent individuals. In mating pool formation, a random number is generated. After for each individual membership degree to which generated number belongs is calculated. Individual with highest membership degree is selected. This process repeat until mating pool size is equal to population size. Figure 2 show the fuzzy roulette wheel selection mechanism for 4 individuals in Figure 1.

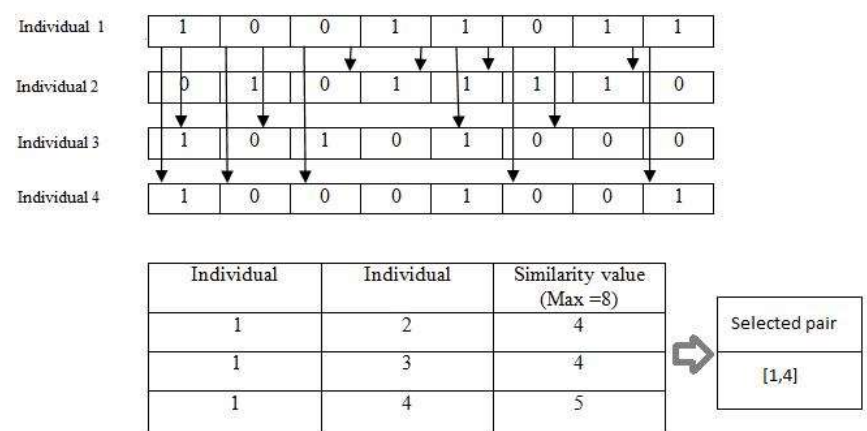

Fig. 1: Procedure of assigning individual to partition of roulette wheel .

CGA adopt a special crossover operator which uses the hierarchical algorithm to form clusters. Individuals in the mating pool are divided into two clusters using hierarchical clustering algorithm. In the hierarchical algorithm, single linkage procedure given in eq (2) is apply to estimate similarity between the

\section{CLUSTERED GENETIC ALGORITHM FOR ${ }^{\text {two clusters. }}$}

\section{MULTIDMENSIONAL KNAPSACK PROBLEM}

In this work, clustered genetic algorithm is developed for multidimensional knapsack problem. CGA is explained in algorithm 2. CGA uses an advanced selection method which employee fuzzy and roulette wheel selection called fuzzy roulette wheel selection. Selection mechanism always choose first individual and assigned it to first partition of roulette wheel.

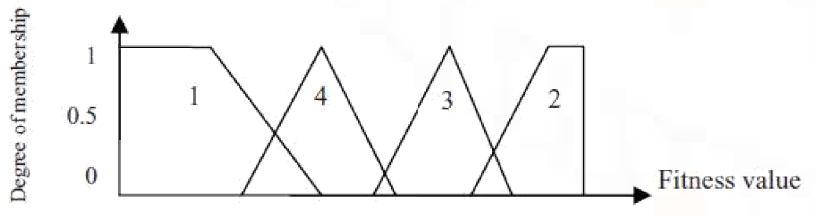

Fig. 2: Fuzzy roulette wheel.

$$
\begin{gathered}
\mathrm{S}(\mathrm{X} ; \mathrm{Y})=\mathrm{M} \mathrm{AX} \mathrm{fs}(\mathrm{x} ; \mathrm{y}) \mathrm{g} \\
\mathrm{x} 2 \mathrm{X} ; \mathrm{y} 2 \mathrm{Y}
\end{gathered}
$$


Where $\mathrm{X}$ and $\mathrm{Y}$ are two clusters and $\mathrm{s}(\mathrm{x}, \mathrm{y})$ stand for similarity between individuals $\mathrm{x}$ and $\mathrm{y}$. A pair of offsprings are generated by mating of a random parent from first cluster and a random parent from second cluster. One point crossover operator is employed. This step is continued N/2-1 times. Random mutation is performed for each offspring to keep diversity and to defeat the problem of premature convergence.

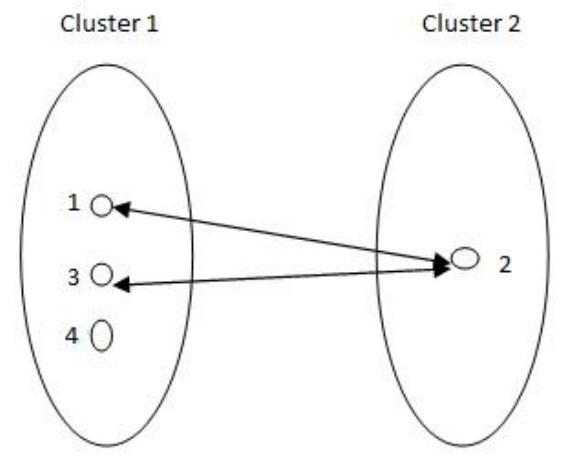

Fig. 3: Selection of parent pair for crossover.

\begin{tabular}{|c|c|c|c|c|c|c|c|c|}
\hline Individual 1 & 1 & 0 & 0 & 1 & 1 & 0 & 1 & 1 \\
\hline \multirow[t]{2}{*}{ Individual 2} & 0 & 1 & 0 & 1 & 1 & 1 & 1 & 0 \\
\hline & & & & & \multicolumn{4}{|c|}{ Crossover point } \\
\hline Offspring 1 & 1 & 0 & 0 & 1 & 1 & 1 & 1 & 0 \\
\hline Offspring 2 & 0 & 1 & 0 & 1 & 1 & 0 & 1 & 1 \\
\hline
\end{tabular}

Fig. 4: One point crossover.

\section{EXPERIMENTAL RESULTS AND DISCUSSION}

To show CGA is better technique to GA, experiments has carried out over 30 standard problems for multidimensional knapsack.

\section{Algorithm 2 Clustered Genetic Algorithm (CGA)}

Initialize the control parameters ;

Initialize randomly $\mathrm{N}$ individuals as initial population $\mathrm{P}(\mathrm{G})$; while stopping criterion(s) doesn't meet do
i.Choose individuals to create mating pool via fuzzy roulette wheel selection operator.

ii. Create two clusters of individuals using hierarchical clustering algorithm .

iii. (iii)Produce new individuals by using crossover operator with a random parent from cluster 1 and a random parent from cluster 2 .

iv. Mutate obtained individuals using mutation operator.

v. Evaluate fitness value of new individuals.

vi. Add new individuals with population.

vii. Sort population with respect to fitness value.

viii. Choose top $\mathrm{N}$ individuals as population of next generation.

end while

Return the fittest individual as the solution.

\section{A. Experimental Environment}

GA and CGA depict in previous section were implementd for multidimensional Knapsack. Experiments were de-signed to estimate average mean error and average mean execution time for GA and CGA. Data set for multidimen-sional knapsack is available at http://people.brunel.ac.uk/ mastjjb/jeb/orlib/files/mknap2.txt. Crossover rate $\mathrm{CR}=$ 0.7 and mutation rate $\mathrm{MR}=0.01$. The experiments were conducted on 7 th generation intel core $\mathrm{i}-7-7700 \mathrm{k}$ processor $(4.2 \mathrm{GHz})$ and coded in $\mathrm{c}++$ whose compilation is done using Dev c ++ compiler.

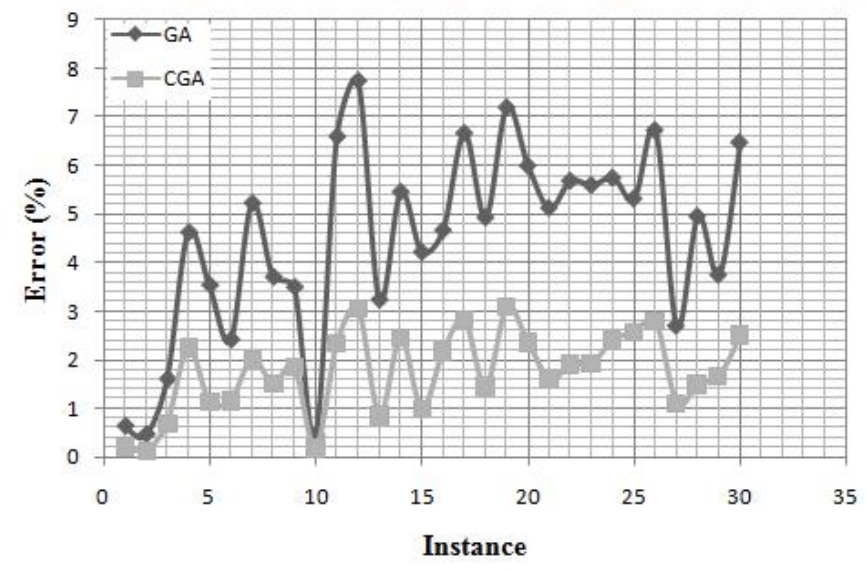

Fig. 5: Error comparision between GA and CGA. 


\section{B. Results and Analysis}

Experimental results of GA and CGA for MDKPs are given in Table I and Table II respectively. Column 1 denote instance no and column 2 represent MDKP, column 3 and 4 show number of knapsacks and number of objects corresponding to problem, columns 5 denotes the optimal value, columns 6-10 keeps the output value of five run, simulation statical information is given in columns 11-14 and column 15 show mean time taken in execution. GA and CGA has average mean error $4.49 \%$ and $1.764 \%$ respectively while GA and CGA has average mean execution time 2.34 seconds and 2.34 seconds respectively. CGA has considerable less average mean error in comparison of GA but CGA has slightly higher average mean execution time in comparison of GA. Figure 5 plot the average mean error against the problem instance and Figure 6 plot the average mean execution time against the problem instance.

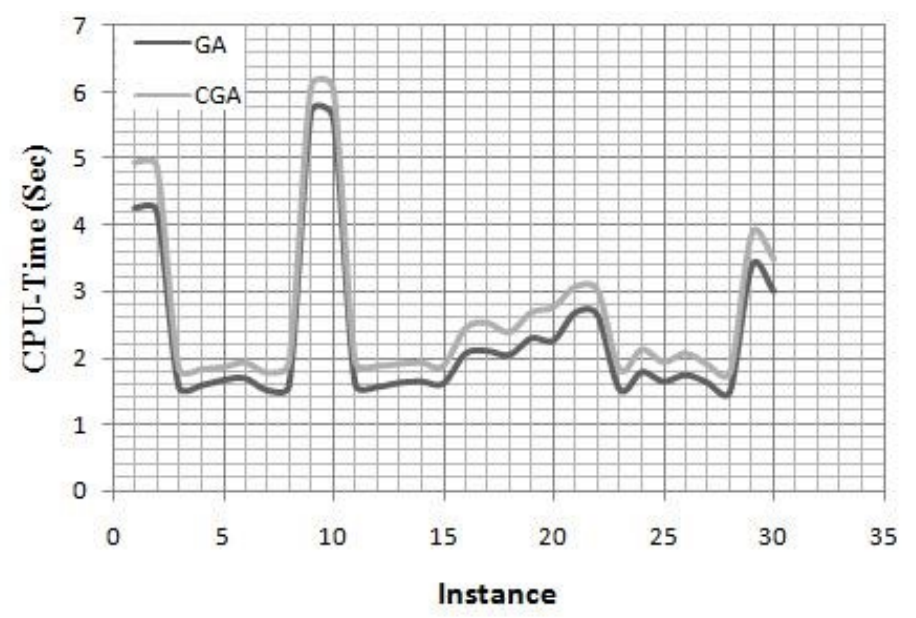

Fig. 6: CPU running time comparison between GA and CGA.

\section{CONCLUSION AND FUTURE WORK}

This paper addressed multidimensional knapsack problem via the cluster genetic algorithm to find optimal. CGA employ the fuzzy roulette selection mechanism for individual selection to form mating pool. CGA adopts a special kind of crossover operator in which uses hierarchical clustering algorithm to form two clusters from mating pool. A pair of offspring is generated by mating of a random parent from first cluster and a random parent from second cluster. CGA performance has examined against GA w.r.t 30 standard MDKPs over two criterion i.e average mean error and average mean execution time.
As GA and CGA experimental results are shown, CGA has better performance than GA for MDKP. A comparative study of different mutation operators with CGA will be studied in the future work.

\section{REFERENCES}

1) Weingartner, H.M. and Ness, D.N., 1967. Methods for the solution of the multidimensional 0/1 knapsack problem. Operations Research, 15(1), pp.83-103.

2) Petersen, C.C., 1967. Computational experience with variants of the Balas algorithm applied to the selection of R\&D projects. Management Science, 13(9), pp.736-750.

3) Weingartner, H.M., $1974 . \quad$ Mathematical programming and the analysis of capital budgeting problems. London: Kershaw.

4) McMillan, C. and Plaine, D.R., 1973. Resource allocation via 01 pro-gramming. Decision Sciences, 4, pp.119-132.

5) Meier, H., Christofides, N. and Salkin, G., 2001. Capital budgeting under uncertaintyan integrated approach using contingent claims analysis and integer programming. Operations Research, 49(2), pp.196-206.

6) Kleinmuntz, D.N. and Kleinmuntz, C.E., 2001. Multiobjective capital budgeting in not-for-profit hospitals and healthcare systems. unpublished paper, October.

7) Gearing, C.E., Swart, W.W. and Var, T., 1973. Determining the opti-mal investment policy for the tourism sector of a developing country. Management science, 20(4-part-i), pp.487-497.

8) Gavish, B. and Pirkul, H., 1982. Allocation of databases and processors in a distributed computing system. Management of Distributed Data Processing, 31, pp.215-231.

9) Chajakis, E. and Guignard, M., 1992, October. A model for delivery of groceries in vehicle with multiple compartments and Lagrangean approximation schemes. In Proceedings of Congreso Latino Ibero-Americano de Investigacin de Operaciones e Ingeniera de Sistemas. 
International Journal of Trend in Scientific Research and Development (IJTSRD) ISSN: 2456-6470

10) Gilmore, P.C. and Gomory, R.E., 1966. The theory and computation of knapsack functions. Operations Research, 14(6), pp.1045-1074.

11) Bellman, R., 1957. Dynamic Programming Princeton University Press Princeton. New Jersey Google Scholar.

12) Straszak, A., Libura, M., Sikorski, J. and Wagner, D., 1993. Computer-assisted constrained approval voting. Group Decision and Negotiation, 2(4), pp.375-385.

13) Vasquez, M. and Hao, J.K., 2001. A logicconstrained knapsack formu-lation and a tabu algorithm for the daily photograph scheduling of an earth observation satellite. Computational Optimization and Applications, 20(2), pp.137-157.

14) Whitley, Darrell. "An executable model of a simple genetic algorithm." Foundations of genetic algorithms 2, no. 1519 (2014): 45-62.

15) Martins, J.P., Neto, C.B., Crocomo, M.K., Vittori, K. and Delbem, A.C., 2013, June. A comparison of linkage-learning-based genetic algorithms in multidimensional knapsack problems. In Evolutionary Computation (CEC), 2013 IEEE Congress on (pp. 502-509). IEEE.
16) Khuri, S., Bck, T. and Heitktter, J., 1994, April. The zero/one multiple knapsack problem and genetic algorithms. In Proceedings of the 1994 ACM symposium on Applied computing (pp. 188193). ACM.

17) Hoff, A., Lkketangen, A. and Mittet, I., 1996, November. Genetic algorithms for $0 / 1$ multidimensional knapsack problems. In Proceedings Norsk Informatikk Konferanse (pp. 291-301).

18) Rudolph, G. and Sprave, J., 1996, September. Significance of locality and selection pressure in the grand deluge evolutionary algorithm. In International Conference on Parallel Problem Solving from Nature (pp. 686-695). Springer Berlin Heidelberg.

19) Chu, P.C. and Beasley, J.E., 1998. A genetic algorithm for the multidi-mensional knapsack problem. Journal of heuristics, 4(1), pp.63-86.

20) Cotta, C. and Troya, J.M., 1998. A hybrid genetic algorithm for the 01 multiple knapsack problem. In Artificial neural nets and genetic algorithms (pp. 250-254). Springer Vienna.

\begin{tabular}{|c|c|c|c|c|c|c|c|c|c|c|c|c|c|c|}
\hline \multirow[t]{2}{*}{$\begin{array}{l}\text { Sr } \\
\text { no }\end{array}$} & \multirow{2}{*}{$\begin{array}{c}\text { Test } \\
\text { Proble } \\
\text { ms }\end{array}$} & \multirow[t]{2}{*}{$\mathrm{m}$} & \multirow[t]{2}{*}{$\mathrm{n}$} & \multirow{2}{*}{$\begin{array}{l}\text { Opt } \\
\text { ima } \\
\text { I }\end{array}$} & & \multicolumn{3}{|c|}{$\begin{array}{c}\text { Number of } \\
\text { Runs }\end{array}$} & \multirow[b]{2}{*}{5} & \multirow[b]{2}{*}{ Max } & \multicolumn{2}{|c|}{$\begin{array}{l}\text { Statistical } \\
\text { Information }\end{array}$} & \multirow[b]{2}{*}{$\begin{array}{l}\% \\
\text { Err }\end{array}$} & \multirow[t]{2}{*}{$\begin{array}{l}\text { Time } \\
\text { (s) }\end{array}$} \\
\hline & & & & & 1 & 2 & 3 & 4 & & & Min & Avg & & \\
\hline 1 & SENT01 & 30 & 60 & 7772 & 7712 & 7736 & 7725 & 7719 & 7723 & 7736 & 7712 & 7723 & $\begin{array}{c}0.6 \\
3\end{array}$ & 4.27 \\
\hline 2 & SENT02 & 30 & 60 & 8722 & 8690 & 8662 & 8702 & 8669 & 8682 & 8702 & 8662 & 8681 & $\begin{array}{c}0.4 \\
6\end{array}$ & 4.23 \\
\hline 3 & $\begin{array}{c}\text { WEING } \\
1\end{array}$ & 2 & 28 & $\begin{array}{c}1412 \\
78\end{array}$ & $\begin{array}{c}1379 \\
02\end{array}$ & $\begin{array}{c}1388 \\
04\end{array}$ & $\begin{array}{c}1386 \\
02\end{array}$ & $\begin{array}{c}1399 \\
03\end{array}$ & $\begin{array}{c}13990 \\
4\end{array}$ & $\begin{array}{c}13990 \\
4\end{array}$ & $\begin{array}{c}13790 \\
2\end{array}$ & $\begin{array}{c}1390 \\
23\end{array}$ & $\begin{array}{c}1.6 \\
0\end{array}$ & 1.58 \\
\hline 4 & $\begin{array}{l}\text { WEING } \\
2\end{array}$ & 2 & 28 & $\begin{array}{c}1308 \\
83\end{array}$ & $\begin{array}{c}1244 \\
53\end{array}$ & $\begin{array}{c}1257 \\
52\end{array}$ & $\begin{array}{c}1249 \\
73\end{array}$ & $\begin{array}{c}1239 \\
89\end{array}$ & $\begin{array}{c}12498 \\
3\end{array}$ & $\begin{array}{c}12575 \\
2\end{array}$ & $\begin{array}{c}12398 \\
9\end{array}$ & $\begin{array}{c}1248 \\
30\end{array}$ & $\begin{array}{c}4.6 \\
2\end{array}$ & 1.60 \\
\hline 5 & $\begin{array}{l}\text { WEING } \\
3\end{array}$ & 2 & 28 & 95667 & 92296 & $\begin{array}{c}9199 \\
8\end{array}$ & $\begin{array}{c}9229 \\
2\end{array}$ & 92398 & 92451 & 92451 & $\begin{array}{c}9199 \\
8\end{array}$ & 92287 & $\begin{array}{c}3.5 \\
3\end{array}$ & 1.68 \\
\hline 6 & $\begin{array}{c}\text { WEING } \\
4\end{array}$ & 2 & 28 & $\begin{array}{c}1193 \\
37\end{array}$ & $\begin{array}{c}1166 \\
25\end{array}$ & $\begin{array}{c}1164 \\
41\end{array}$ & $\begin{array}{c}1159 \\
98\end{array}$ & $\begin{array}{c}1164 \\
59\end{array}$ & $\begin{array}{c}11679 \\
2\end{array}$ & $\begin{array}{c}11679 \\
2\end{array}$ & $\begin{array}{c}11599 \\
8\end{array}$ & $\begin{array}{c}1164 \\
63\end{array}$ & $\begin{array}{c}2.4 \\
1\end{array}$ & 1.71 \\
\hline 7 & $\begin{array}{c}\text { WEING } \\
5\end{array}$ & 2 & 28 & 98796 & 93667 & $\begin{array}{c}9366 \\
2\end{array}$ & $\begin{array}{c}9344 \\
2\end{array}$ & 93778 & 93631 & 93778 & $\begin{array}{c}9344 \\
2\end{array}$ & 93636 & $\begin{array}{c}5.2 \\
2\end{array}$ & 1.53 \\
\hline 8 & $\begin{array}{l}\text { WEING } \\
6\end{array}$ & 2 & 28 & $\begin{array}{c}1306 \\
23\end{array}$ & $\begin{array}{c}1244 \\
50\end{array}$ & $\begin{array}{c}1260 \\
93\end{array}$ & $\begin{array}{c}1260 \\
92\end{array}$ & $\begin{array}{c}1261 \\
72\end{array}$ & $\begin{array}{c}12615 \\
8\end{array}$ & $\begin{array}{c}12617 \\
2\end{array}$ & $\begin{array}{c}12445 \\
0\end{array}$ & $\begin{array}{c}1257 \\
93\end{array}$ & $\begin{array}{c}3.7 \\
0\end{array}$ & 1.59 \\
\hline
\end{tabular}


International Journal of Trend in Scientific Research and Development (IJTSRD) ISSN: 2456-6470

\begin{tabular}{|c|c|c|c|c|c|c|c|c|c|c|c|c|c|c|}
\hline 9 & $\begin{array}{c}\text { WEING } \\
7\end{array}$ & 2 & $\begin{array}{c}10 \\
5\end{array}$ & $\begin{array}{c}1095 \\
445\end{array}$ & $\begin{array}{c}1054 \\
402\end{array}$ & $\begin{array}{l}1057 \\
806\end{array}$ & $\begin{array}{c}1059 \\
803\end{array}$ & $\begin{array}{l}1057 \\
804\end{array}$ & $\begin{array}{l}1056 \\
405\end{array}$ & $\begin{array}{c}10598 \\
03\end{array}$ & $\begin{array}{c}1054 \\
402\end{array}$ & $\begin{array}{l}1057 \\
244\end{array}$ & $\begin{array}{c}3.4 \\
9\end{array}$ & 5.72 \\
\hline 10 & $\begin{array}{c}\text { WEING } \\
8\end{array}$ & 2 & $\begin{array}{c}10 \\
5\end{array}$ & $\begin{array}{c}6243 \\
19\end{array}$ & $\begin{array}{c}6214 \\
22\end{array}$ & $\begin{array}{c}6217 \\
98\end{array}$ & $\begin{array}{c}6206 \\
42\end{array}$ & $\begin{array}{c}6218 \\
82\end{array}$ & $\begin{array}{c}62176 \\
1\end{array}$ & $\begin{array}{c}62188 \\
2\end{array}$ & $\begin{array}{c}62064 \\
2\end{array}$ & $\begin{array}{c}6215 \\
01\end{array}$ & $\begin{array}{c}0.4 \\
5\end{array}$ & 5.64 \\
\hline 11 & $\begin{array}{c}\text { WEISH } \\
01\end{array}$ & 5 & 30 & 4554 & 4214 & 4298 & 4288 & 4178 & 4292 & 4298 & 4178 & 4254 & $\begin{array}{c}6.5 \\
9\end{array}$ & 1.62 \\
\hline 12 & $\begin{array}{c}\text { WEISH } \\
02\end{array}$ & 5 & 30 & 4536 & 4197 & 4182 & 4178 & 4181 & 4187 & 4197 & 4178 & 4187 & $\begin{array}{c}7.7 \\
4\end{array}$ & 1.58 \\
\hline 13 & $\begin{array}{c}\text { WEISH } \\
03\end{array}$ & 5 & 30 & 4115 & 3990 & 3987 & 3976 & 3973 & 3984 & 3990 & 3973 & 3982 & $\begin{array}{c}3.2 \\
3\end{array}$ & 1.64 \\
\hline 14 & $\begin{array}{c}\text { WEISH } \\
04\end{array}$ & 5 & 30 & 4561 & 4314 & 4317 & 4323 & 4302 & 4304 & 4323 & 4302 & 4312 & $\begin{array}{c}5.4 \\
5\end{array}$ & 1.66 \\
\hline 15 & $\begin{array}{c}\text { WEISH } \\
05\end{array}$ & 5 & 30 & 4514 & 4311 & 4309 & 4388 & 4303 & 4309 & 4388 & 4303 & 4324 & $\begin{array}{c}4.2 \\
1\end{array}$ & 1.63 \\
\hline 16 & $\begin{array}{c}\text { WEISH } \\
06\end{array}$ & 5 & 40 & 5557 & 5331 & 5333 & 5307 & 5228 & 5291 & 5333 & 5228 & 5298 & $\begin{array}{c}4.6 \\
6\end{array}$ & 2.08 \\
\hline 17 & $\begin{array}{c}\text { WEISH } \\
07\end{array}$ & 5 & 40 & 5567 & 5186 & 5193 & 5177 & 5244 & 5180 & 5244 & 5177 & 5196 & $\begin{array}{c}6.6 \\
6\end{array}$ & 2.12 \\
\hline 18 & $\begin{array}{c}\text { WEISH } \\
08\end{array}$ & 5 & 40 & 5605 & 5302 & 5368 & 5352 & 5214 & 5309 & 5368 & 5214 & 5329 & $\begin{array}{c}4.9 \\
2\end{array}$ & 2.06 \\
\hline 19 & $\begin{array}{c}\text { WEISH } \\
09\end{array}$ & 5 & 40 & 5246 & 4901 & 4848 & 4898 & 4886 & 4812 & 4901 & 4812 & 4869 & $\begin{array}{c}7.1 \\
9\end{array}$ & 2.31 \\
\hline 20 & $\begin{array}{c}\text { WEISH } \\
10\end{array}$ & 5 & 50 & 6339 & 5916 & 5923 & 5978 & 5981 & 5972 & 5981 & 5916 & 5954 & $\begin{array}{c}5.9 \\
9\end{array}$ & 2.28 \\
\hline 21 & $\begin{array}{c}\text { WEISH } \\
11\end{array}$ & 5 & 50 & 5643 & 5387 & 5362 & 5324 & 5336 & 5361 & 5387 & 5324 & 5354 & $\begin{array}{c}5.1 \\
2\end{array}$ & 2.70 \\
\hline 22 & $\begin{array}{c}\text { WEISH } \\
12\end{array}$ & 5 & 50 & 6339 & 5984 & 5972 & 5988 & 5977 & 5974 & 5988 & 5972 & 5979 & $\begin{array}{c}5.6 \\
8\end{array}$ & 2.66 \\
\hline 23 & HP1 & 4 & 28 & 3418 & 3220 & 3198 & 3224 & 3278 & 3215 & 3278 & 3198 & 3227 & $\begin{array}{c}5.5 \\
9\end{array}$ & 1.54 \\
\hline 24 & HP2 & 4 & 35 & 3186 & 3016 & 3010 & 3078 & 2999 & 2912 & 3078 & 2912 & 3003 & $\begin{array}{c}5.7 \\
4\end{array}$ & 1.80 \\
\hline 25 & PB1 & 4 & 27 & 3090 & 2916 & 2924 & 2942 & 2918 & 2930 & 2942 & 2916 & 2926 & $\begin{array}{c}5.3 \\
1\end{array}$ & 1.66 \\
\hline 26 & PB2 & 4 & 34 & 3186 & 2978 & 2986 & 2962 & 2971 & 2963 & 2986 & 2962 & 2972 & $\begin{array}{c}6.7 \\
2\end{array}$ & 1.76 \\
\hline 27 & PB4 & 2 & 29 & 95168 & 92372 & $\begin{array}{c}9270 \\
8\end{array}$ & $\begin{array}{c}9250 \\
4\end{array}$ & 92666 & 92780 & 92780 & $\begin{array}{c}9237 \\
2\end{array}$ & 92606 & $\begin{array}{c}2.6 \\
9\end{array}$ & 1.64 \\
\hline 28 & PB5 & 10 & 20 & 2139 & 2037 & 2032 & 2043 & 2012 & 2041 & 2043 & 2012 & 2033 & $\begin{array}{c}4.9 \\
5\end{array}$ & 1.50 \\
\hline 29 & PB6 & 30 & 40 & 776 & 706 & 740 & 765 & 758 & 766 & 766 & 706 & 747 & $\begin{array}{c}3.7 \\
4\end{array}$ & 3.40 \\
\hline 30 & PB7 & 30 & 37 & 1035 & 977 & 992 & 966 & 973 & 932 & 992 & 932 & 968 & $\begin{array}{c}6.4 \\
7\end{array}$ & 3.02 \\
\hline
\end{tabular}

TABLE I: Result of Genetic Algorithm For Multidimensional Knapsack Problems. 
International Journal of Trend in Scientific Research and Development (IJTSRD) ISSN: 2456-6470

\begin{tabular}{|c|c|c|c|c|c|c|c|c|c|c|c|c|c|c|}
\hline \multirow[t]{2}{*}{$\begin{array}{l}\text { Sr } \\
\text { no }\end{array}$} & \multirow{2}{*}{$\begin{array}{c}\text { Test } \\
\text { Proble } \\
\text { ms }\end{array}$} & \multirow[t]{2}{*}{$m$} & \multirow[t]{2}{*}{ n } & \multirow{2}{*}{$\begin{array}{c}\text { Opt } \\
\text { ima } \\
1 \\
\end{array}$} & & \multicolumn{3}{|c|}{$\begin{array}{l}\text { Number of } \\
\text { Runs }\end{array}$} & \multirow[b]{2}{*}{5} & & \multicolumn{2}{|c|}{$\begin{array}{l}\text { Statistical } \\
\text { Information }\end{array}$} & \multirow[b]{2}{*}{$\begin{array}{c}\% \mathrm{Er} \\
\mathrm{r}\end{array}$} & \multirow[t]{2}{*}{$\begin{array}{l}\text { Time } \\
\text { (s) }\end{array}$} \\
\hline & & & & & 1 & 2 & 3 & 4 & & $\begin{array}{c}\mathrm{Ma} \\
\mathrm{x}\end{array}$ & Min & Avg & & \\
\hline 1 & SENT01 & 30 & 60 & 7772 & 7762 & 7746 & 7758 & 7752 & 7747 & $\begin{array}{c}776 \\
2\end{array}$ & 7746 & 7754 & 0.23 & 4.95 \\
\hline 2 & SENT02 & 30 & 60 & 8722 & 8712 & 8707 & 8705 & 8716 & 8710 & $\begin{array}{c}871 \\
6\end{array}$ & 8705 & 8710 & 0.14 & 4.89 \\
\hline 3 & WEING1 & 2 & 28 & $\begin{array}{c}1412 \\
78 \\
\end{array}$ & $\begin{array}{c}1401 \\
77 \\
\end{array}$ & $\begin{array}{c}1401 \\
83 \\
\end{array}$ & $\begin{array}{c}1401 \\
96 \\
\end{array}$ & $\begin{array}{c}1401 \\
78\end{array}$ & $\begin{array}{c}14077 \\
1\end{array}$ & $\begin{array}{l}140 \\
771\end{array}$ & $\begin{array}{c}14017 \\
7\end{array}$ & $\begin{array}{c}1403 \\
01\end{array}$ & 0.69 & 1.83 \\
\hline 4 & WEING2 & 2 & 28 & $\begin{array}{c}1308 \\
83\end{array}$ & $\begin{array}{c}1278 \\
62 \\
\end{array}$ & $\begin{array}{c}1278 \\
04\end{array}$ & $\begin{array}{c}1281 \\
08\end{array}$ & $\begin{array}{c}1279 \\
03\end{array}$ & $\begin{array}{c}12799 \\
3\end{array}$ & $\begin{array}{l}127 \\
993\end{array}$ & $\begin{array}{c}12780 \\
4\end{array}$ & $\begin{array}{r}1279 \\
934 \\
\end{array}$ & 2.25 & 1.82 \\
\hline 5 & WEING3 & 2 & 28 & 95667 & 94570 & $\begin{array}{c}9458 \\
2 \\
\end{array}$ & $\begin{array}{c}9444 \\
8 \\
\end{array}$ & 94684 & 94556 & $\begin{array}{c}945 \\
82 \\
\end{array}$ & $\begin{array}{c}9444 \\
8 \\
\end{array}$ & 94568 & 1.15 & 1.85 \\
\hline 6 & WEING4 & 2 & 28 & $\begin{array}{c}1193 \\
37 \\
\end{array}$ & $\begin{array}{c}1179 \\
82\end{array}$ & $\begin{array}{c}1179 \\
47\end{array}$ & $\begin{array}{c}1178 \\
92\end{array}$ & $\begin{array}{c}1179 \\
32\end{array}$ & $\begin{array}{c}11794 \\
2\end{array}$ & $\begin{array}{l}117 \\
982\end{array}$ & $\begin{array}{c}11789 \\
2 \\
\end{array}$ & $\begin{array}{c}1179 \\
39 \\
\end{array}$ & 1.17 & 1.92 \\
\hline 7 & WEING5 & 2 & 28 & 98796 & 96694 & $\begin{array}{c}9670 \\
2 \\
\end{array}$ & $\begin{array}{c}9688 \\
4 \\
\end{array}$ & 96879 & 96861 & $\begin{array}{c}968 \\
79 \\
\end{array}$ & $\begin{array}{c}9669 \\
4 \\
\end{array}$ & 96804 & 2.02 & 1.77 \\
\hline 8 & WEING6 & 2 & 28 & $\begin{array}{c}1306 \\
23\end{array}$ & $\begin{array}{c}1285 \\
03\end{array}$ & $\begin{array}{c}1286 \\
64\end{array}$ & $\begin{array}{c}1287 \\
04\end{array}$ & $\begin{array}{c}1286 \\
30 \\
\end{array}$ & $\begin{array}{c}12863 \\
9\end{array}$ & $\begin{array}{l}128 \\
704\end{array}$ & $\begin{array}{c}12850 \\
3 \\
\end{array}$ & $\begin{array}{c}1286 \\
28 \\
\end{array}$ & 1.53 & 1.91 \\
\hline 9 & WEING7 & 2 & $\begin{array}{c}10 \\
5\end{array}$ & $\begin{array}{c}1095 \\
445\end{array}$ & $\begin{array}{c}1074 \\
998\end{array}$ & $\begin{array}{c}1076 \\
681\end{array}$ & $\begin{array}{c}1075 \\
662\end{array}$ & $\begin{array}{c}1074 \\
552\end{array}$ & $\begin{array}{c}1073 \\
902\end{array}$ & $\begin{array}{c}107 \\
668 \\
1 \\
\end{array}$ & $\begin{array}{c}1073 \\
902\end{array}$ & $\begin{array}{c}1075 \\
159\end{array}$ & 1.85 & 6.10 \\
\hline 10 & WEING8 & 2 & $\begin{array}{c}10 \\
5 \\
\end{array}$ & $\begin{array}{c}6243 \\
19 \\
\end{array}$ & $\begin{array}{c}6231 \\
10 \\
\end{array}$ & $\begin{array}{c}6229 \\
90 \\
\end{array}$ & $\begin{array}{c}6231 \\
84 \\
\end{array}$ & $\begin{array}{c}6232 \\
08 \\
\end{array}$ & $\begin{array}{c}62311 \\
3 \\
\end{array}$ & $\begin{array}{l}623 \\
208 \\
\end{array}$ & $\begin{array}{c}62299 \\
0 \\
\end{array}$ & $\begin{array}{c}6231 \\
21 \\
\end{array}$ & 0.19 & 6.08 \\
\hline 11 & WEISH01 & 5 & 30 & 4554 & 4428 & 4462 & 4448 & 4436 & 4461 & $\begin{array}{c}446 \\
2\end{array}$ & 4428 & 4447 & 2.35 & 1.93 \\
\hline 12 & WEISH02 & 5 & 30 & 4536 & 4402 & 4398 & 4372 & 4410 & 4403 & $\begin{array}{c}440 \\
3\end{array}$ & 4372 & 4397 & 3.06 & 1.87 \\
\hline 13 & WEISH03 & 5 & 30 & 4115 & 4083 & 4076 & 4083 & 4071 & 4082 & $\begin{array}{c}408 \\
3\end{array}$ & 4071 & 4079 & 0.87 & 1.90 \\
\hline 14 & WEISH04 & 5 & 30 & 4561 & 4461 & 4448 & 4457 & 4434 & 4445 & $\begin{array}{c}446 \\
1\end{array}$ & 4434 & 4449 & 2.46 & 1.92 \\
\hline 15 & WEISH05 & 5 & 30 & 4514 & 4476 & 4487 & 4462 & 4462 & 4468 & $\begin{array}{c}448 \\
7 \\
\end{array}$ & 4462 & 4452 & 1.00 & 1.87 \\
\hline 16 & WEISH06 & 5 & 40 & 5557 & 5441 & 5436 & 5392 & 5446 & 5463 & $\begin{array}{c}546 \\
3 \\
\end{array}$ & 5392 & 5436 & 2.18 & 2.44 \\
\hline 17 & WEISH07 & 5 & 40 & 5567 & 5395 & 5407 & 5437 & 5437 & 5414 & $\begin{array}{c}543 \\
7 \\
\end{array}$ & 5395 & 5392 & 2.83 & 2.52 \\
\hline 18 & WEISH08 & 5 & 40 & 5605 & 5518 & 5507 & 5532 & 5522 & 5536 & $\begin{array}{c}553 \\
6 \\
\end{array}$ & 5507 & 5523 & 1.46 & 2.38 \\
\hline 19 & WEISH09 & 5 & 40 & 5246 & 5076 & 5084 & 5102 & 5078 & 5080 & $\begin{array}{c}510 \\
2 \\
\end{array}$ & 5076 & 5084 & 3.09 & 2.68 \\
\hline 20 & WEISH10 & 5 & 50 & 6339 & 6201 & 6198 & 6182 & 6180 & 6184 & $\begin{array}{c}620 \\
1 \\
\end{array}$ & 6180 & 6189 & 2.37 & 2.76 \\
\hline 21 & WEISH11 & 5 & 50 & 5643 & 5558 & 5537 & 5529 & 5568 & 5568 & $\begin{array}{c}556 \\
8 \\
\end{array}$ & 5529 & 5552 & 1.61 & 3.07 \\
\hline 22 & WEISH12 & 5 & 50 & 6339 & 6236 & 6199 & 6214 & 6208 & 6233 & $\begin{array}{c}623 \\
6 \\
\end{array}$ & 6199 & 6218 & 1.91 & 3.02 \\
\hline
\end{tabular}


International Journal of Trend in Scientific Research and Development (IJTSRD) ISSN: 2456-6470

\begin{tabular}{|c|c|c|c|c|c|c|c|c|c|c|c|c|c|c|}
\hline 23 & HP1 & 4 & 28 & 3418 & 3368 & 3332 & 3357 & 3362 & 3341 & $\begin{array}{c}336 \\
8\end{array}$ & 3332 & 3352 & 1.93 & 1.82 \\
\hline 24 & HP2 & 4 & 35 & 3186 & 3109 & 3112 & 3106 & 3104 & 3114 & $\begin{array}{c}311 \\
4\end{array}$ & 3104 & 3109 & 2.42 & 2.12 \\
\hline 25 & PB1 & 4 & 27 & 3090 & 3012 & 3001 & 3017 & 3005 & 3015 & $\begin{array}{c}301 \\
7\end{array}$ & 3001 & 3010 & 2.58 & 1.93 \\
\hline 26 & PB2 & 4 & 34 & 3186 & 3094 & 3088 & 3116 & 3098 & 3089 & $\begin{array}{c}309 \\
8\end{array}$ & 3088 & 3097 & 2.79 & 2.06 \\
\hline 27 & PB4 & 2 & 29 & 95168 & 94207 & $\begin{array}{c}9399 \\
8\end{array}$ & $\begin{array}{c}9410 \\
6\end{array}$ & 94103 & 94111 & $\begin{array}{c}942 \\
07\end{array}$ & $\begin{array}{c}9399 \\
8\end{array}$ & 94105 & 1.12 & 1.89 \\
\hline 28 & PB5 & 10 & 20 & 2139 & 2099 & 2111 & 2104 & 2106 & 2115 & $\begin{array}{c}211 \\
5\end{array}$ & 2099 & 2107 & 1.50 & 1.76 \\
\hline 29 & PB6 & 30 & 40 & 776 & 763 & 758 & 759 & 766 & 769 & 769 & 758 & 763 & 1.68 & 3.87 \\
\hline 30 & PB7 & 30 & 37 & 1035 & 1008 & 1017 & 1012 & 1006 & 1002 & $\begin{array}{c}101 \\
7\end{array}$ & 1002 & 1009 & 2.51 & 3.49 \\
\hline
\end{tabular}

TABLE II: Result of Clustered Genetic Algorithm for Multidimensional Knapsack Problems. 